\title{
REVIEW
}

\section{RESEARCH IN THE FIELD OF MEDICAL SCIENCES}

\author{
SAROJ JAYASINGHE ${ }^{\prime \prime}$ and GEETHIKA YAPA ${ }^{2}$ \\ 'Department of Medicine, University of Colombo, Colombo 8. \\ "National Science Foundation (NARESA), 47/5, Maitland Place, Colonbo 7.
}

(Received: 05 May 1.998; accepted: 02 October 1998)

\begin{abstract}
Although Indigenous Medicine was practised in Sri Lanka as far back as the 4 th century BC, Western Medicine was introduced only in the beginning of the 14 th century by the Portuguese. During British rule the practice of western medicine was rapidly developed. However an organized attempt at research in this field began only in 1900. Recognizing the need for co-ordinated research and devclopment activities, the state created the National Science Council (NSC) in 1968. Since then the NSC and its successor the Natural Resources Enerry and Science Authority (NARESA) have been in the forefront of developing medical research in Sri Lamka. Upto $1997 \mathrm{jt}$ has sponsored over 200 research projects in the medical sciences, of which 51 projects have yielded postgraduate degrees. In addition to NARESA, several local as well as foreign organisations are currently involved in funding medical research in Sri Lanka. Some issues concerning the researchers in medical sicences are also discussed in this paper.
\end{abstract}

Key words: Funds, medical sciences, research.

\section{History of Medical Sciences and Research in Sri Lanka}

The Mahawamsa and several lithic inscriptions unearthed in Anuradhapura and Polonnaruwa indicate that Sri Lankans have a rich tradition of medical practice. There are references to hospitals as early as $4^{\text {th }}$ century BC. ${ }^{1}$ Ancient Ayurvedic text on ola leaves, ruins of hospitals (e.g. in Mihintale, Medirigiriya,Polonnaruwa), troughs for medicated immersion therapy, all indicate the existence of hospital based care of the sick. Research during this era was probably limited to careful observation of phenomena and interpretation of links between events and disorders. Thus herbal drugs and other health related belief systems like astrology may have developed on an empirical basis.

Western medicine was introduced to Sri Lanka by the Portuguese in 1505, and they built several hospitals. The Dutch extended the services by building a few more hospitals. Rapid development in the health sector began after 1802, when the maritime province of Ceylon became a British colony. The early phase was characterised by concern for the health of the troops, control of communicable diseases like smallpox and cholera, and care of the estate labour/personnel. ${ }^{2}$

\footnotetext{
Corresponding author
}

This article was originally written for the Supplenent to mark the 25 th year of publication of the Journal of the National Science Council. 
'Thus during the $19^{\text {th }}$ century research was directed more towards the priorities of military medicine. Several studies were made of the high morbidity rates in white soldiers ${ }^{3}$ e.g. dysentery, enteric fever and iron deficiency anaemia. The services expanded rapidly after 1858 when an independent Civil Medical Department was established. Though one of the earliest proposals to set up a medical school was made in the late 1830 s, the Colombo Medical School was opened only in 1870 . Ten years later it was upgraded to a College. The diploma of Licenciate of Medicine and Surgery (LMS) which was granted by the College was given recognition by the General Medical Council of Great Britain in 1887. In 1942, the Ceylon University College and the Ceylon Medical College were amalgamated to create the Universitynt of Science formed in 1944. Policy makers and politicians responded (somewhat belatedly) in 1968 with the creation of the National Science Council, (predecessor of NARESA). ${ }^{6}$ However, several initiatives to implement a comprehensive policy in science and technology (including research) have failed. However, NARESA has taken a lead role in giving direction for research by funding priority areas using a process of consensus and consultation between scientists and policy makers.

Resources for research and Cladosporridium wernecki. During the 1940s to 1960s several researchers documented descriptions of disease/ disorders (e.g. Professor Rajasuriya on leptospirosis, Professor Karunaratne's monograph on rhinosporidiosis). ${ }^{5}$

The recent clinical research interests include occupational lung diseases, haemoglobinopathies, organophosphate poisoning, molecular biology and clinical features of parasitic diseases (malaria and filariasis), aflatoxins, epidemiology and aetiology of non-communicable diseases, amoebic liver diseases, nutrition, diabetes mellitus, intestinal infections, specific antidotes for viper bites etc. These were conducted mainly by clinicians and scientists in the state sector, sometimes with foreign collaboration. There is a conspicuous absence of research in the private sector, except those conducted by a few general practitioners. Pharmaceutical industry sponsors a few projects while they "donate" considerable sums of money for conferences, seminars and meetings. Research in the ayurvedic sector is done in the Bandaranayake Memorial Ayurvedic Research Institute at Nawinna.

Basic scientific research has been based mainly within the Universities (e.g. Malaria Research Unit) with a few exceptions (e.g. Institute of fundamental Studies, Medical Research Institute). Notable advances have been made in immunology of malaria, DNA probes for filariasis, organophosphate poisoning, peripheral neuropathies, cytokines in diarrhoeal disease, entomology and risk factors in cardiovascular disorders. 


\section{ROLE OF NARESA}

From its inception, the National Science Council and its successor NARESA have. played an active role in co-ordinating medical research in Sri Lanka. Their role has been to give direction, facilitate, fund, train researchers and disseminate findings related to basic and applied research.

\section{Direction for research:}

A country requires directed research and development for its advancement. Researchers agitated for such a policy for science through the Ceylon Association for the Advancement of Science formed in 1944. Policy makers and politicians responded (somewhat belatedly) in 1968 with the creation of the National Science Council, (predecessor of NARESA). ${ }^{6}$ However, several initiatives to implement a comprehensive policy in science and technology (including research) have faild. However, NARESA has taken a lead role in giving direction for research by funding priority areas using a process of consensus and consultation between scientists and policy makers.

\section{Resources for research:}

Funds : Since its inception 203 research projects in the Medical Sciences have been funded by NARESA accouriting to $12.8 \%$ of its resource allocation. From 1992-1997 the grants for Medical Sciences were approximately Rs. 12.6 million (or US\$240,000 using a conversion rate of Rs $50=1 \mathrm{US} \$$ ), a comparatively small quantum if about Rs. 2.1 million or US $\$ 40,000$ per year by international standards. This compares favourably with the amount allocated for research by the Universities, (which amount to about Rs. 300,000 for a Faculty of Medicine), and the annual vote of Rs. 3-5 million (U.S. $\$ 60,000$ ) for research by the Ministry of Health. ${ }^{7}$ However, the contribution by NARESA is small in comparison to the funds being made available to the Ministry of Health via grants from the World Health Organistion (US\$2.7 million), the World Bank (US\$3.9 million) and UNICEF (US\$0.77 million) for the year 1995. However, the percentage of these utilised for research is not available, except that the WHO has committed US $\$ 17,500$ in 1995 for Research Promotion and Development. Most of the funds allocated by foreign aid agencies are for service oriented work though a proportion is used for commissioning reports (which are unfortunately not widely distributed). Data is not available on the number of projects funded by these Agencies.

The funds allocated by NARESA are well utilised and $15 \mathrm{PhDs}$ and 36 other degrees have been completed during the past 25 years (MSc, MOhil and MD). This is a total of 51 projects to fulfill degrees (an average of 2.04 per year). This is a significant contribution in basic research for a local non-university institution. Several contemporary research projects (e.g. molecular biology of parasitic diseases, 
epidemiology of non-communicable diseases, nutrition, etc.) have received financial assistance from NARESA. Furthermore NARESA has provided a much needed impetus to researchers who are required to complete a dissertation as a prerequisite for a degree. During the period 1992 to 1996 alone, 57 such projects received funding and 36 of them were completed. Several of these projects were community based or clinical studies of relevance to Sri Lanka.

The total budget for health sector research is not available. However, the Research and Development budget for Sri Lanka is reported to be only $0.18 \%$ of GDP and yet there are not enough "takers". ${ }^{9}$ This is a sad indictment on the scientific community.

Physical resources: NARESA does not provide infrastructure facilities (e.g. laboratory space). The financial support is used by researchers to obtain physical resources, personnel and expenditure for travel.

The following major settings are used by researchers for their projects.

1. Ministry of Health: hospitals, clinics and Medical Research Institute

2. Universities - Faculties of Medicine and Faculties of Science: especially the laboratory based studies.

3. Private Sector: Private practitioners and Private hospitals

4. Institute of Fundamental Studies

5. Community based studies

Human resources: The requirement of a dissertation or a thesis for a postgraduate degree by the Postgraduade Institute of Medicine is an incentive for research. Several of these are funded by NARESA. The Ministry of Health (except for those in the MRI) hardly offers any incentives or support to embark on research programmes. The funds available in the Provincial Ministries of Health for research is negligible. The National Workshop on Research Management conducted in Apri] 1998 by the Ministry of Health and WHO was an attempt to assist the development of capacity for research management.

Together with other professional organisations, NARESA has taken an active role in training researchers in methodology and scientific presentations. Seminars and workshops on research methodology and Getting Research into Practice (GRIPS) have been held with the participation of the Sri Lanka Medical Association and Professional Colleges. Furthermore, there are grants available from NARESA for researchers to travel abroad in order to present their work at international seminars and workshops. 


\section{Dissemination of information and research work:}

NARESA also has an excellent library, multimedia facilities and Internet facilities to assist researchers. The newsletter provides regular information on fellowship programmes, conferences and workshops of interest. The Journal is a forum for publication of research work subject to peer review. Workshops are held for researchers to exchange views and information. Merit awards are given in appreciation of high quality research work.

\section{OTHER ORGANISATIONS IN THE ARENA OF SCIENTIFIC RESEARCH}

More recently policy related research has received an impetus with the Health Systems Research Programme of the WHO. The World Bank, United Nations Development Fund (UNDP), International Development Research Centre of the Canadian Government (IDRC) and Asian Development Bank (ADB) too have stepped into health related research activities. Funds from these donors are usually obtained through the Ministry of Health.

Sources other than NARESA for funding in the Medical Sciences include:

\section{Universities}

2. Institute of Fundamental Studies

3. Ministry of Health

4. Pharmaceutical companies

5. Professional associations and Colleges (e.g. Ceylon College of Physicians)

6. Individual contributions by well-wishers or personal funds of the researchers.

\section{FU'TURE ISSUES IN RESEARCH}

Several issues confront the research community. Three priority areas are: lack of a coordinated plan to develop research; problems related to prioritising research; inadequate resources for research.

Lack of a coordinated plan to develop research : The need to have a coordinated plan for development of research in the health sector has emerged as a priority and is being addressed in the National Workshop on Research Management (April 1998). Focal points are to be identified in the Centre and Provinces and research management capabilities would be strengthened. NARESA is an active participant in this activity.

Future research priorities : The general direction of research should take cognisance of the development strategy adopted by the country. An obligation 
of the research community should be to focus on identifying and prioritising existing and emerging health problems facing the country, based on the strategic plan for the country. The role of organisations like NARESA in this activity would be pivotal in impressing upon policy makers the need to articulate the direction being taken by the country. For example, if a clear strategy of industrialisation is stated, it would highlight the importance of appropriate occupational health related applied research and issues related to environmental pollution.

Once the crucial development goals and challenges are identified, institutions like NARESA should continue the process of identifying priority research areas, preferably by consensus with wide participation of institutions and individual researchers and funding organisations. A workshop methodology or a consensus conference is likely to yield satisfactory results. Prioritisation of research does not mean individual researchers should be restricted from pursuing their interests. Such freedom, which is vital for an inquiring mind, should be encouraged. However funds from a national budget should be directed more towards resolving national problems and issues rather than the intellectual curiosity of researchers.

Inadequate resources for research: The current expenditure on research in the health sector invested by the Ministry of Health is less than $1 \%$ of the health budget. This is comparatively low when compared to other countries. With the current growth rate of the economy, it seems unlikely that there would be a substantial increase in the resources made available unless researchers lobbied for more. One option would be to utilise funds made available by foreign donors to develop research in our country. However, there exists a potential danger of concentrating our resources on research questions, which are a priority for the donor, rather than us! Institutions like NARESA, Universities and IFS should have a resource base to counter this tendancy and give leadership at this juncture. Pooling of resources (equipment, human resources and infrastructure) available to different institutions, avoidance of duplicate funding, lobbying for funds, collaborating with private sector for research initiatives and diverting funds for research (for example from the sponsorship of medical conferences to research) are some options available to us. It would be wise to thrust such issues on the policy agenda in order to meet these challenges facing our country.

\section{References}

1. Uragoda C.G. (1987). A history of medicine in Sri Lanka. p. 25. Sri Lanka Medical Association, Colombo.

2. Uragoda C.G. (1987). A history of medicine in Sri Lanka. pp. 81-85. Sri Lanka Medical Association. Colombo. 
3. Uragoda C.G. (1987). A history of medicine in Sri Lanka. p. 175. Sri Lanka Medical Association, Colombo.

4. Arseculeratne S.N. (1994). Aldo Castellani - a paradigm for a medical career, Journal of the Ceylon College of Physicians 27: 36-44.

5. Ministry of Health and Indigenous Medicine (1998). Health development in Sri Lanka. Modern Medicine, Vol. 1.

6. Natural Resources, Energy and Science Authority of Sri Lanka . (1995). National $S \& T$ Policy and a Plan of Action.

7. Report of the Presidential Task Force on Formulation of a National Health Policy for Sri Lanka, 1992.

8. Ministry of Health and Indigenous Medicine (1995). Annual Health Bulletin. p. 41.

9. Natural Resources, Energy and Science Authority of Sri Lanka. Newsietter, December 1996. 